\title{
Analysis on the Improvement of China's College Student Affairs Efficiency from Comparative Perspective
}

\author{
Zichao Wang ${ }^{1, a}$, Yi Zou ${ }^{2, \text { b }}$ \\ 1,2 Sichuan University of Science \& Engineering, Zigong Sichuan,643000 \\ a email, ${ }^{b}$ email
}

Keywords: Colleges and Universities, Student Affairs, Efficiency

\begin{abstract}
Under the background of new era, it is necessary to the useful experience of the Western Modern Universities to enhance the effectiveness of college student Affairs, such as "student-oriented" concept, comprehensive Affairs contents, professional and special Affairs team, standard and efficient management system. Based on this, China's colleges and universities need to reform the current student Affairs system to make it more standardized and efficient, which can be more conducive to promoting students' all-round development, enhancing staff quality, and promoting teachers tutor system. It is also necessary to cultivate and promote students' self-management, establish corresponding organizations, and support their development to achieve the purpose of promoting students' development.
\end{abstract}

\section{Introduction}

In recent years, the situation of China's college student Affairs in our country is becoming increasingly complex, with both opportunities and challenges. First of all, under the influence of reform and opening up, on the one hand, China's college student Affairs get to learn from various advanced experience of the world; on the other hand, college student Affairs needs to be better so as to adapt to the demand of students' international vision. Secondly, the ever increasing influence of the Internet, especially the popularity of mobile Internet among students, greatly expands students' horizons, which leads to the diversification trend in students' thought, setting higher demands for student Affairs for sure. Thirdly, the objects of student Affairs are mainly the new age students born after 1990s who have distinct personalities and more explicit self seeking, which also requires adjustments in the managerial and educational mode of colleges and universities.

In July 2010, Article 40 of the chapter 13 in the National Medium and Long-term Education Reform and Development Plan Outline (2010-2020) issued by The Party Central Committee and the State Council officially put forward that "it is necessary to improve the modern university system with Chinese characteristics". In 2013, the Third Plenary Session of 18th CPC Central Committee proposed to improve the governance structure of colleges and universities, which sets higher demand for the reform of the system and methods of student Affairs in Colleges and universities. At the same time, the increasingly fierce competition among major colleges and universities also make the reform and innovation become an urgent task.

The creation of modern university system started from the University of Berlin establish in Humboldt, German in 1810, which is nearly two centuries ago from now. The main functions of modern universities can be summarized as follows: imparting and developing knowledge, scientific research, talents training, and serving the society, which all are closely related to student Affairs. It is a natural mission of each university to cultivate excellent students. The thesis aims to put forward some useful suggestions for the improvement of the efficiency of China's college student Affairs on th basis of the experience of western modern university students.

\section{The requirements of western modern university system for student affairs}

Throughout the development process of modern universities' student Affairs, the following 
experience and principles can be concluded for us to learning from:

Student-oriented" concept. The concept change of student Affairs in western developed countries' universities experienced five major stages, including "student management (supervise and restrict students like parents)", "independent of student Affairs (distinguish student Affairs from academic affairs, pay attention to extracurricular counseling and tutoring for students)", "student service (take student service as the concept, provide humanized service for different students", "focus on students' development (pay attention to the protection of the students' legal rights, regard them as equal partner)", "all-round service for students' growth ( focus on the integration of class and extracurricular learning, take education responsibility together with teachers)”.

The five development stage is a layer-layer progressive and step-by-step improving relationship. At one time, college students are regarded as immature individuals with imperfect personality and are susceptible to various problems, which is why they have to be subject to various Schools' management with harsh rules and regulations. The student Affairser's duty is to exercise strict supervision and control of students through forms such as command and punishment. When it comes to the all-round service for students' comprehensive development, "student-orientated" concept is the core.

The actual "student-orientated" concept is to adhere to the students' standard. The primary goal of student Affairs is to promote the all-round development of each student. All the resources of the school should be integrated with this goal in order to cooperate with students' study and promote their all-round development. School teachers and other management staff should Affairs together to fully grasp various circumstances of students' growth, and formulate targeted training programs according to different individuals and their different development stages. Meanwhile, "student-orientated" concept emphasizes that education should start from students' needs and take software and hardware conditions needed in students' growth into full consideration, so as to mobilize students' enthusiasm. And various departments and educators can promote the all-round development of students on the basis of high division of labor.

The real "student-orientation" is to establish a comprehensive environment that is conducive to students' growth. In western colleges and universities, "education" is no longer knowledge learning and accumulation, and student Affairs no longer a simple "management" of students, but became something that includes all non-academic affairs, and that is involved in "the affairs in students' education and the promotion of the comprehensive development of students ". It derives from the concept of "full service to students", which uses planned goal setting, assessment, teaching, consulting and environmental management to adapt to the rapid development of higher education and the needs of students' growth. It offers comprehensive and individualized guidance for college students from various aspects, including enrollment, entrance education, university career guidance, course selection instruction, learning improvement, physical and mental health, accommodation management, extracurricular interests and skills expansion, difficulty assistance and employment guidance, etc.

With the establishment of students' all-round development service concept, student Affairs begins to fully integrate with various school Affairss, especially its combination and interaction with academic affairs, which is a division of labor and a cooperation that can have further integration while maintaining professional. All Affairs aims to cultivate students with all-round development.

Standard and efficient management system. Although the western and China's political system are different, and there is a huge difference between their management system of colleges and universities, "a stone from other hills may serve to polish the jade of this one". In addition to the concept, Affairs content, practitioners' quality of western developed countries' student Affairs, their student management system is also worth us to study and learn from:

Flat management system with few layers.An efficient management organization should streamline its layers as simple as possible to make it a highly flat one. In addition, it should expand the scope of management to continuously improve the efficiency and effectiveness of management. 
The representative students Affairs in western modern universities is only at the university level, with various functional departments serving all students directly without corresponding institutions at faculty level, prompting efficient management. This flattening student Affairs system enables Affairsing process shortening, fully division of labor, and decentralization, which makes it easy to take students' needs as the driving force and thus be able to achieve integrated services. In addition, fewer levels also boost information spreading and quick and efficient feedback, which can help to gain a timely understanding of students' dynamics and can also put the latest educational theory into practice.

Implementing a first-level management at school level can concentrate and integrate the whole school resources to the greatest extent, ensuring that each student can gain equal access to the university's services when counseling and serving. The integration of resources can not only avoid repeating post and counselors' “individual combat” in China's student Affairs, but can also gives full play to team advantage, thus providing students with professional service. It can save time and improve service efficiency when faced with specialized student Affairsers.

More outsourcing business, less self burden. In order to focus on academic and educational affairs, many western colleges and universities outsource services such as logistics services (such as catering, accommodation, etc.) to social firms. The benefits of business outsourcing is to fully mobilize social resources through the standardization of market operation, and to enhance service efficiency and keep improving service effect to reduce their own burden through means such as competition. Some student Affairs in other countries achieves economies of scale, cost- reduction, and the standardization and improvement of service levels through inter-university and cross-regional integration services.

Humanized and efficient service.Students Affairs covers many aspects, making college students (especially freshmen) be prone to be at a loose end for numerous departments, not knowing who they should turn to once there is a problem. Therefore, it is an effective way to solve the problem and improve the efficiency of student Affairs, by integrating various student services within an office space to be accepted and sorted out by a unified reception according to the degree of difficulty to decide solutions, or a complete question database, or solved by one-to-one experts. It has also become a common practice in modern universities.

In the (mobile) Internet era, the humanized one-stop service measures of colleges and universities do not only boast of physical platform such as student services building (Hall), but also make full use of virtual electronic platforms such as effective service website (or even a mobile client), enabling students to gain more efficient access to information and services.

The combination of professional affairs team and supervisor system. With the unceasing improvement of western developed countries' student Affairs system, their student Affairs has developed into a specialized occupation with a stable employment team. But compared with China's student Affairs system that depends on individuals such as counselors to deal with a variety of complicated Affairs, theirs has a clear and detailed division of labor according to different Affairsing fields. Especially in specified fields such as psychological counseling and career guidance, they have high demand for practitioners' profession, education, qualification and Affairs experience. What's more, there are also corresponding specifications for practitioners' job level, prompting the improvement of practitioners' skills.

The complete division of labor, strong profession, high professional quality of students Affairs has the following advantages: first of all, division of labor, each staff has his or her specialized professional field according to responsible range, which can be conducive to enhancing Affairsing ability through stable training channels; secondly, perfect discipline system, together with the support of corresponding educational theory and research, which can help continuously improve the efficiency of student Affairs; thirdly, with professional basis, staff can have diverse learning and experience sharing platforms; fourthly, high social recognition degree of student Affairs, coupled with the basis and protection of perfect laws and regulations. 
When taking the enhancement of students' comprehensive development as the study object, we should not be confined to student Affairs team but should take important education group-teachers into consideration. Supervisor system was first carried out by University of Oxford and University of Cambridge in the UK and was most widespread in universities and colleges in America and Britain. Supervisor, a function rather than a title, is responsible for the guidance of students' schoolAffairs and helps them plan their study plan to do ideological and moral cultivation. Supervisor system not only helps students firm their beliefs in learning to improve academic performance, but can also promote the improvement of students' personality through words and deeds. For teachers, being supervisors can also enhance their professional quality and management skills, inspiring them to continuously improve their own quality.

Students' full autonomy. The autonomy in western universities began in the early eleventh Century by Italy Bologna university, which allowed students to be responsible for school affairs. Later because of teachers' increasingly important position as academic authority, they gained a greater influence on school management. The shift promoted student autonomy into silence. Later, with the gradual implementation of campus democratization, and the disintegration of the parent-like management, a new student autonomous organization gradually established.

After World War II, the modern student autonomous organization gradually flourished and improved. On the one hand, student autonomy facilitates student's campus life, coupled with the integration of extracurricular life that is more conducive to students development; on the other hand, schools also conform to the trend by introducing students' autonomous organization into the daily affairs of school management to be in consultation with the students and enable students to better arrange their study. Of course, modern student autonomy is totally different with that of in Middle Ages, with the former emphasizing the identity of students "academic citizen" by training students' self management and security rights to enable them better development rather than handling various school affairs. In 1988, the United Nations announced the Lima Declaration, whose article 9 and article 10 clearly stipulates that students enjoy the right to freedom, and that college students are academic citizens, which is not only recognition of student autonomy, but also an indication of the world recognition of educational democracy concept.

\section{Countermeasures and Suggestions to Improve Student Affairs}

Under the improvement of modern university system background, it can be seen from the useful lessons drawn from Western Universities that, China's concept of college student Affairs should put people first and further integrate Affairs content to cover various aspects of students' study and life, that the Affairsing staff should be more professional and specialized, and that the management system should be more efficient. As a reference, combined with the specific situation of China's colleges and universities, there are several measures to improve the effectiveness of the Affairs of college students in our country. By taking this as a criterion and combining with the specific situation of China's colleges and universities, here are several measures to promote the efficiency of China's college student Affairs

Put students first, and reform student Affairs mechanism system. Reform system.Under the guidance of the "people-oriented" concept, it is naturally that college student Affairs should be student-oriented. However, when it comestible to put theory into practice, it is necessary to reform the Affairs system and mechanism. Currently, China's college student Affairs mainly overseen by Students Affair Department, which deals with numerous and jumbled content and lacks labor of division. The integration of student Affairs mentioned above, mainly means that student Affairs should cover all aspects of students' study and life, rather than to have one department taken charge of all Affairs, which is prone to result in low efficiency due to lack of labor of division.

Therefore, some scholars suggest to take "the traditional students affairs management, including recruitment, employment, finance (including Affairs-study plan and poverty-lifting), and 
psychological counseling out of the functions of Students Affair Department, and establish a separate center or department to operate independently. School administrative institutions set up employment center, Affairs-study plan center and psychological counseling center, all with full-time staff of professional background and professional experience to carry out services and consulting business directly to students of the school as a whole.” In this way, with professional affairs being dealt with by the professionals, it can boost the efficiency and effectiveness of student Affairs. Students Affair Department can specialize in students' service, such as students' ideological and political education, students' management Affairs, students consulting services and student activities (this part may need to coordinate with the Communist Youth League).

Innovation mechanism.Obviously, it is far from enough for student Affairs to only rely on special staff (China mainly based on counselor), lacking the most important educational groups - teachers. Teachers who have unique knowledge and personal charm play an important role in students' development. However, the contact between China's college students and teachers is obviously insufficient.

In view of this, China's universities can learn from the tutorial system of Western universities. The greatest advantage of the tutorial system is to impart tutors' professional knowledge and effective learning methods to students in a most direct way. No doubt, it is the most direct and efficient for them to guide students' study. In addition, the tutorial system can also enable teachers to know the learning situation and dynamic idea of students. With teacher's words and deeds, it can not only help students to establish development direction, make teaching activities more targeted to better promote students' learning, but can also shape students’ spiritual character.

Cultivate and promote the students' self management.Therefore, it is necessary to establish "governance mechanism with separation of powers checks in academic power, administrative power, and political power." The modern university with Chinese characteristics contains four aspects, including "Party committee leadership, president's management of university, professors governing academic studies, and democratic management". As far as the student Affairs is concerned, the "democratic management" needs good students' self-management, which is not only the requirements of national education system reform (including government's efficient system and efficient internal governance system), but also the need for academic innovation and the promotion of social progress.

The characteristics of students' self-management.Good students' self-management must have the following characteristics:

First, the equal status among students, teachers, and administrative personnel can be realized through the appropriate institutional arrangements to enable students to participate in the school management and to enter the relevant decision-making process.

Secondly, based on self - management organization such as the student union, the democratic conference is the main discussion and participation mode. There are corresponding organizations and smooth channels when encounter problems closely related to students' interests.

Thirdly, university management does not only recognize and support students' self-management, but there are also corresponding management institutions that have student representatives and pay attention to students' participation in the administrative and academic decision-making process, in order to improve the quality of decision making.

Establish and improve the form of students' self-management organization.Today, the basic organization unit of China's college students is still class. Therefore, the class committee should not only be the basic organization of college students' self-management, but also be an important platform to enhance their self-management consciousness and ability

Student union organization is another important platform for college students' self-management.Management departments of colleges and universities should delegate power to student union, help them formulate regulations, and establish the corresponding self-management organization and standard, so as to enable student union to truly become their own organization that 
can adjust its Affairs content and methods according to their own needs, serving for students in a real sense.

College student associations are spontaneous organizations organized by students according to students' hobbies and interests, and an important stage for students to display, exercise and improve themselves. The number and quality of a university's student association directly reflect the activity, ability and management style of its students. College associations' role in students contact, campus culture inheritance and creation, and talents training and cultivation is difficult to be replaced by any other organizations. School administrators should relax the access mechanism of associations, and do well in supervision and protection to help improve the quality of various associations.

In addition to self-management organizations mentioned above, there are students' dormitory management, canteen management, classroom and other academic groups' management, which will not be discussed in detail. Of course, with self-management organization, there are the following three aspects of Affairs needing to be done:

First of all, grant students' self-management organization full self management power to guarantee its chance and right to participate in school affairs. Whether students have the right to participate in the discussion and decision-making of the rules and regulations that are closely related with them can reflect the implementation situation of a school's "people-oriented" and "mass line". Only by giving students self-management can effectively eliminate the psychological distance between managers and students and help to improve the rationality of school decision-making.

Secondly, give financial support to promote students' self-management, self-discipline and self-improvement. Currently, some organizations recruit members with an important aim, i.e., to collect fees, which deprives student association of its original and various meaning. Therefore, schools should have special funds to guarantee students' self-management activities.

Thirdly, establish student affairs arbitration institutions to accept student complaints and protect the interests of students with perfect organizational structure and effective designed procedures.

\section{References}

[1] Tao Xu. Study on college student Affairs in the new era[M]. Southwest Jiaotong University press, 2007

[2] Minghua Ma. The characteristics and innovation of modern college student Affairs [M]. Chinese Social Science Publishing House, 2007

[3] Xiaobo Huang. The construction of student Affairs specialized system and counselor's core competence[M]. Beijing Normal University press, 2010

[4] Pei Feng. Innovation of China's college student affairs management mode [M]. Beijing: China Renmin University Press, 2009

[5] Dongchang He (editor-in-chief). Important Education Literature of the people's Republic of China (1975 - 1949) [M]. Hainan Press, 1998

[6] [U.S.] Abraham Flexner. Modern university theory: analysis on the universities in Britain, the United States, and Germany [M]. Hangzhou: Zhejiang Education Press, 2001.

[7] Junzong Zhang. Modern university system [M]. Beijing: China Social Science Press, 2004

[8] Li Li. Study on the professional development of China's College Counselors[D]. Nanjing Normal University, 2009

[9] Taylor,H.“The Philosophical Foundations of General Education”National Society for the 50 Study of Education,“Year book on General education”,1952.

[10] Robert B.Young,Guiding Valuesand Philosophy”,InKomives,Susan R,Woodard,Jr.,Dudley B.,\&Associates."Student Services:A Handbook for the Profession"(Third Edition),Jossey-BassInc.,1996. 
[11] Fang Ming. Study on China's college student Affairs management mode [D]. Nanchang University, 2012 